\title{
Did transmission of Helicobacter pylori from humans cause a disease outbreak in a colony of Stripe-faced Dunnarts (Sminthopsis macroura)?
}

\author{
Alison L Every', Lynne Selwood², Natalia Castano-Rodriguez ${ }^{3}$, Wei Lư ${ }^{4}$, Helen M Windsor ${ }^{4}$, Janet LK Wee', \\ Agnieszka Swierczak', Barry J Marshall ${ }^{4}$, Nadeem O Kaakoush³ ${ }^{3}$ Hazel M Mitchell ${ }^{3}$, Philip Sutton ${ }^{{ }^{*}}$
}

\begin{abstract}
Since the discovery that Helicobacter pylori causes a range of pathologies in the stomachs of infected humans, it has become apparent that Helicobacters are found in a diverse range of animal species where they are frequently associated with disease. In 2003 and 2004, there were two outbreaks of increased mortality associated with gastric bleeding and weight-loss in a captive colony of the Australian marsupial, the Stripe-faced Dunnart (Sminthopsis macroura). The presence of gastric pathology led to an investigation of potential Helicobacter pathogenesis in these animals. Histological examination revealed the presence of gastritis, and PCR analysis confirmed the presence of Helicobacter infection in the stomachs of these marsupials. Surprisingly, sequencing of 165 rRNA from these bacteria identified the species as $\mathrm{H}$. pylori and PCR confirmed the strain to be positive for the important pathogenesis factor, cagA. We therefore describe, for the first time, an apparent reverse zoonotic infection of Stripe-faced Dunnarts with H. pylori. Already prone to pathological effects of stress (as experienced during breeding season), concomitant $H$. pylori infection appears to be a possible essential but not sufficient co-factor in prototypic gastric bleeding and weight loss in these marsupials. The Stripe-faced Dunnart could represent a new model for investigating Helicobacter-driven gastric pathology. Infections from their human handlers, specifically of $H$. pylori, may be a potential risk to captive colonies of marsupials.
\end{abstract}

\section{Introduction}

The discovery of Helicobacter pylori eventually led to a realization that infection of the human stomach with this bacterium is a key etiological factor in the development of peptic ulcer disease and gastric adenocarcinoma [1-3]. Another important consequence of that discovery has been the subsequent identification of an ever growing, seemingly ubiquitous family of Helicobacter species that infect the gastrointestinal tract of virtually all animals examined. In fact, many Helicobacter infections are believed to be pathogenic and possibly responsible for a wide range of conditions in numerous animal species (reviewed in [4,5]). For example, natural Helicobacter infections have been linked with gastritis in small and large cats, dogs, pigs and ferrets [6-10], abortion in

\footnotetext{
* Correspondence: psutton@unimelb.edu.au

${ }^{1}$ Centre for Animal Biotechnology, School of Veterinary Science, The

University of Melbourne, Melbourne, VIC 3010, Australia Full list of author information is available at the end of the article
}

sheep [11], colitis and hepatitis in rhesus monkeys [12], ulcers in dolphins and whales [13] and diarrhea in cats and parrots $[14,15]$.

In this report we describe two outbreaks of deaths in a captive colony of an Australian marsupial, the Stripefaced Dunnart (Sminthopsis macroura), that were associated with bleeding in the stomach possibly due to infection by the human pathogen, H. pylori.

\section{Materials and methods Stripe-faced Dunnarts}

The Stripe-faced dunnarts were housed at the Department of Zoology, University of Melbourne. The colony was held within cages maintained within a purpose built temperature regulated building, in a physical environment in conditions typical for those for housing mice, except that natural lighting was maintained. Animal housing in specially designed cages, the diet formulated for carnivorous insectivorous marsupials and
Ciomed Central 
reproductive monitoring followed the outline given previously [16]. No other animal species were housed in this building. The dunnarts were provided water ad libitum. No dunnarts were killed specifically for this study; stomachs were only collected from animals euthanized either due to illness or for other experimentation approved by the University of Melbourne Science, Optometry \& Vision Sciences and Land \& Environment animal ethics-committee. Animals were weighed at weekly intervals during routine animal husbandry.

\section{Rapid urease test (CLO test)}

Stomach biopsies of 1-2 mm were placed in the gel of a rapid urease test (CLOtest; Kimberly-Clark, Roswell, Georgia, USA). Tests were monitored over a $24 \mathrm{~h}$ period for a color change from yellow to red which indicated the presence of a urease-producing organism in the stomach.

\section{Histological assessment of pathology}

Stomach halves were fixed in $10 \%$ neutral buffered formalin, embedded in paraffin, then $4 \mu \mathrm{m}$-thick sections cut and stained with hematoxylin and eosin.

\section{Detection of Helicobacter infection by genus-specific PCR}

For assessment of Helicobacter infection by PCR, feces were collected, or Dunnart stomachs were opened along the inner curvature and the whole organ homogenized (GmbH Polytron homogenizer; Kinematica, Switzerland). Mucosal scrapings were also collected from the intestine (large and small). DNA was extracted from feces and intestinal scrapings using a QIAamp stool DNA kit (Qiagen, Hilden, Germany), and from the homogenized stomach using the QIAamp tissue DNA kit (Qiagen) according to manufacturer's instructions. A Helicobacter genus PCR targeting a 374 bp fragment of the 16S rRNA gene was performed as previously described [17].

\section{Approaches to cultivate Dunnart gastric Helicobacter}

Dunnart stomachs were collected and homogenized in Brain Heart Infusion broth (BHI; Oxoid, Basingstoke, UK). Homogenate was added to horse blood agar or GSSA plates (as described previously [18]) which were incubated in an anaerobic jar with a microaerophilic gas-generating kit (Oxoid, Basingstoke, UK) for up to 10 days at $37^{\circ} \mathrm{C}$. For the filtration technique, homogenate was placed onto $0.65 \mu \mathrm{m}$ Whatman filter paper (GE Healthcare, Rydalmere, Australia), placed on HBA plates, and incubated at $37^{\circ} \mathrm{C}$ under microaerophilic conditions for $2 \mathrm{~h}$. Filters were then removed and plates incubated at $37^{\circ} \mathrm{C}$ under microaerophilic conditions for up to 10 days.
Gene sequencing of 165 ribosomal RNA, cagA and ureA

Nine DNA samples extracted from Dunnart stomach and intestinal scrapings were subjected to sequencing. PCRs for Helicobacter genes were performed as previously described for $16 S$ rRNA [17], cagA [19] and ureA [20]. DNA sequencing of the positive PCR products was done by means of the BigDye terminator chemistry (Applied Biosystems; Foster City, USA). Sequencing of both the 5' and 3' end of the amplicons occurred in a volume of $20 \mu \mathrm{L}$ consisting of $3.5 \mu \mathrm{L}$ sequencing buffer, $1 \mu \mathrm{L}$ BigDye v3.1, $10 \mathrm{pmol} / \mu \mathrm{L}$ of the required primer, 40-100 ng DNA, and water to make up the final volume. The sequencing program consisted of $96^{\circ} \mathrm{C}$ for $1 \mathrm{~min}, 30$ cycles of $96^{\circ} \mathrm{C}$ for 10 seconds, $50^{\circ} \mathrm{C}$ for $5 \mathrm{~min}$ and $60^{\circ} \mathrm{C}$ for $4 \mathrm{~min}$. The sequences were compared to gene sequences of known identities using the BLASTn search program available through the National Centre for Biotechnology Information (NCBI) website [21].

\section{Results}

\section{Deaths in a Stripe-faced Dunnart colony - 2003}

A colony of Stripe-faced Dunnarts has been in existence for 26 years, initially at La Trobe University (Melbourne, Australia), and then at the Department of Zoology, University of Melbourne. The colony normally has between 60-100 animals in which the sex ratio is $1 / 1$. Death from illness is rare in these animals and in a normal year, total deaths occur at a rate of about $10 \%$ or less of the number of animals in the colony. Most deaths occur as a result of injuries obtained during mating (the breeding season runs from July to December) or old age.

In 2003 however, there was a dramatic rise in the mortality rate of these animals, with $29 \%$ of the Dunnarts (30/104; similar numbers of males and females) dying in the 6 month period from July to December. The dying animals were 1-2 years old and the deaths were not related to old age. Dunnarts usually lose body weight during the breeding season and this weight loss was also notably increased during 2003. Male Dunnarts typically lose an average $12 \%$ body weight from July to December, but in 2003 they lost an average 27.7\%. Similarly, female Dunnarts lost an average 30.3\% during the same period in 2003, compared with a typical average loss of $16 \%$. Figure 1 shows the relative weight loss observed by these Dunnarts in 2003, as compared to weight loss observed in 2006, a typical year in which there was no increased mortality.

The only evident pathology observed at post mortem was that almost half of the animals that died or were culled due to being very sick had severe gastric hemorrhage. Apart from increased weight loss, most animals seemed healthy until 1-2 days before death, although a 


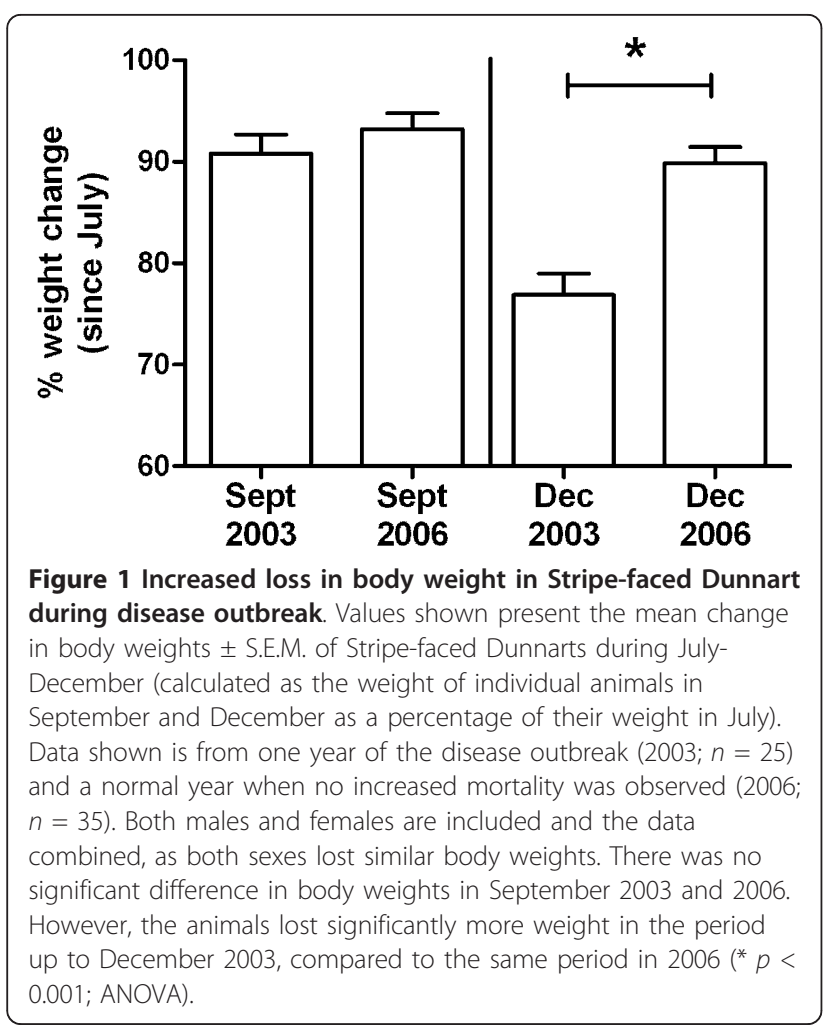

few had black stools (consistent with gastrointestinal bleeding) and signs of anemia (pale snouts and gums).

\section{Deaths in a Stripe-faced Dunnart colony - 2004}

The gastric bleeding present in these animals raised the possibility of gastric ulceration as a result of Helicobacter infection. Therefore, in May 2004, stomachs from two asymptomatic female Dunnarts were tested for Helicobacter infection using the CLO test. These were found to be positive, supportive of a gastric Helicobacter infection. Histological analysis of these stomachs revealed the presence of a relatively mild inflammatory process, marked by lymphoid aggregates in the lamina propria (Figure 2), although no colonizing bacteria in either spiral or coccoid form could be observed in these sections. No severe pathology was evident in these particular sections, although these stomachs were collected outside the breeding season when increased mortality and gastric bleeding was not occurring.

Between July and December 2004 a second incident of increased mortality occurred, with 24 out of 81 (30\%) of the Dunnart colony dying, 6 of which had gastric bleeding.

In several cases in 2003 and 2004, females that were deemed to be pregnant from reproductive monitoring had aborted the litter when they were examined to obtain embryos.

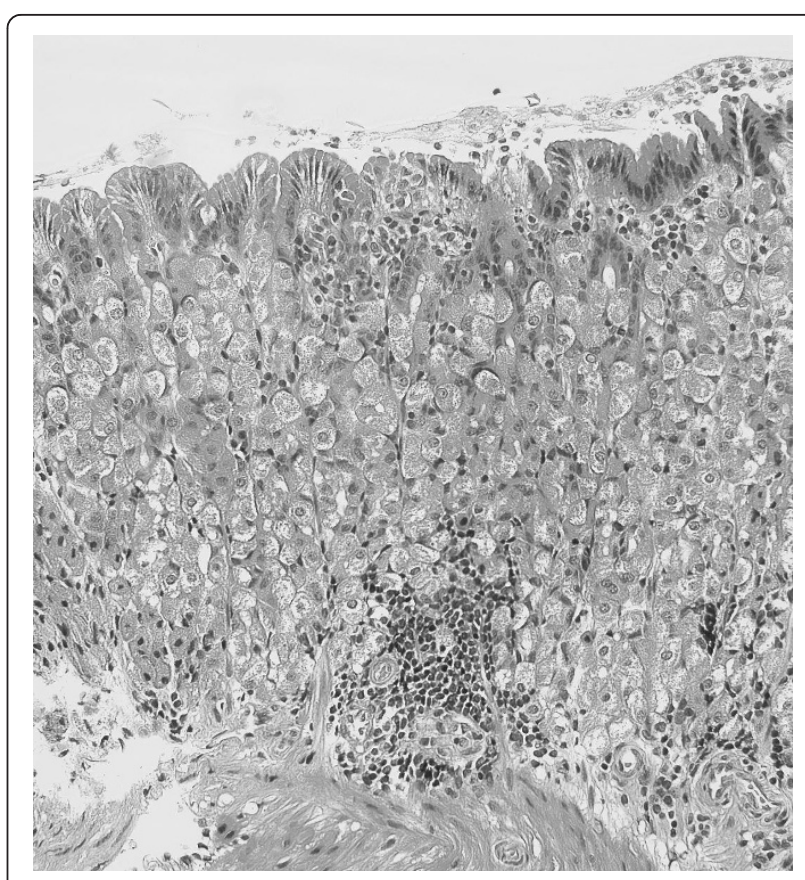

Figure 2 Inflammation in the gastric lamina propria of a Helicobacter-infected Dunnart. An image is shown from an H\&E stained section of gastric corpus, from a Helicobacter-infected Dunnart (magnification $\times 100$ ). The stomach was collected in May 2004

Helicobacter infection in the Dunnart colony 2005-2008 In 2005 , and in subsequent years, the mortality rate returned to normal levels ( $10 \%$ per year) and no further cases of gastric bleeding were observed. However sporadic attempts were made to further examine the apparent gastric Helicobacter infection in these animals. These attempts were limited by the availability of animals for such studies.

In 2006, the presence of Helicobacter in fecal samples collected from male $(n=20)$ and female $(n=20)$ Dunnarts were assessed by genus specific PCR. Using this approach, the feces of equivalent numbers of male (7/ $20)$ and female $(7 / 20)$ Stripe-faced Dunnarts were shown to be colonized with Helicobacter species, providing evidence of the presence of Helicobacters in the GI tract of at least some animals in this colony. Attempts to cultivate Helicobacter from these samples were unsuccessful.

In July 2007, stomachs and intestinal scrapings collected from Dunnarts were analyzed by genus-specific PCR. These showed that $10 / 12$ of the animals examined had gastric Helicobacter infection. Again, attempts to cultivate Helicobacter from the gastric samples were unsuccessful. 


\section{Species identification of Helicobacter infection in the Dunnart stomach}

To identify whether a known or novel Helicobacter species was infecting the Stripe-faced Dunnart colony, the $16 S$ ribosomal RNA (rRNA) Helicobacter gene from these gastric samples was partially sequenced. This indicated that the 16S rRNA gene sequence of Helicobacter infecting the stomachs of Stripe-faced Dunnarts corresponded to $H$. pylori strains originally isolated from different regions of the human gastrointestinal tract including the stomach and intestine. The identity percentages obtained with the sequences were $100 \%$ (Table 1 ).

The important H. pylori virulence factor, cagPAI (cag pathogenicity island) encodes a type-IV secretion system involving cagA. Not all $H$. pylori strains possess this virulence factor, and individuals infected with cagPAI positive strains typically develop more severe gastritis, and have a greatly increased chance of progressing to disease. Urease, an enzyme composed of two subunits ure $A$ and $u r e B$, is essential for the pathogenesis of $H$. pylori in the human stomach because of its ability to neutralize gastric acid through the production of bicarbonate. Analysis using specific PCR primers revealed that the infecting Helicobacter were cagA and ureA positive, and gene sequencing revealed $96 \%$ identity with cagA and $96-98 \%$ identity with ureA from $H$. pylori (Table 1 ).

\section{Natural loss of $H$. pylori infection in the Stripe-faced Dunnart colony}

When samples were collected from 18 female Dunnarts in July of 2008 surprisingly, all of these animals were Helicobacter negative indicating the colony had lost the infection. There is no obvious explanation for the loss of $H$. pylori infection in these animals, as there was no change in husbandry, nor were the Dunnarts treated with any antibiotics during this period.

For clarity, a chronology of the above events is summarized in Table 2. The Dunnart colony in the Zoology
Department at the University of Melbourne was closed in 2009, precluding further study.

\section{Discussion}

Two outbreaks of increased mortality in a colony of the Australian marsupial, the Stripe-faced Dunnart in 2003 and 2004 were associated with gastric bleeding and occurred coincidental with a transient infection of the stomachs of animals in this colony with the human pathogen, H. pylori. Notably, this infecting strain possessed the virulence factor $\operatorname{cag} A$, which suggests the presence of the cagPAI type-IV secretion system, associated with an increased risk of developing gastric cancer or peptic ulcers in humans. While only five of the nine Dunnart samples analyzed were cagA and urea positive, this may be explained by the low amount of Helicobacter DNA in these samples, although the possibility of heterogeneity in the infecting strains cannot be excluded.

It was unfortunate we were unable to cultivate Helicobacter from the Dunnart stomachs, as this may have allowed us to study the level of heterogeneity, if any, of these bacteria in the colony. The initial attempts to cultivate Helicobacter were performed in Perth, Western Australia, on samples sent from Melbourne. The delay caused by collection and transfer of these samples may have limited our ability to isolate the infecting bacteria. However, in later studies we did attempt to cultivate them from fresh gastric tissue. Attempts on fresh tissue using HBA plates failed, not too surprisingly, due to fungal overgrowth. When selective GSSA plates were used, we did manage to initially culture a motile bacterium, but this was subsequently overgrown by a coccoid organism. We next attempted a filtration approach, which successfully restricted contamination by the coccoid organism, but unfortunately also did not allow us to isolate Helicobacter. This may suggest the Helicobacter present in the Dunnarts either had poor motility (an

Table 1 BLASTn retrieval of Helicobacter pylori gene sequences

\begin{tabular}{|c|c|c|c|c|}
\hline BLASTn Retrieve & GenBank accession number & Score (bits) & Identity & E-values \\
\hline Helicobacter pylori clone P13 165 ribosomal RNA gene & EF684928.1 & 699 & $100 \%$ & 0.0 \\
\hline Helicobacter pylori strain CD2 165 ribosomal RNA gene & HM243132.1 & 699 & $100 \%$ & 0.0 \\
\hline Helicobacter pylori strain HP504 165 ribosomal RNA gene & GU449115.1 & 695 & $100 \%$ & 0.0 \\
\hline Helicobacter pylori v225d 165 ribosomal RNA gene & CP001582.1 & 695 & $100 \%$ & 0.0 \\
\hline Helicobacter pylori strain 407D5 165 ribosomal RNA gene & HM099656.1 & 695 & $100 \%$ & 0.0 \\
\hline Helicobacter pylori strain 15818 cytotoxin associated protein III (cagA) gene & AF083352.1 & 1288 & $96 \%$ & 0.0 \\
\hline Helicobacter pylori NCTC 11639 CagA (cagA) gene & GQ161099.1 & 1282 & $96 \%$ & 0.0 \\
\hline Helicobacter pylori strain 114C UreA (ureA) gene & GQ403154.1 & 630 & $96-98 \%$ & $3 e^{-164} 1 e^{-177}$ \\
\hline
\end{tabular}

Helicobacter genus-specific PCR products derived from Dunnart gastric DNA extracts were compared with the $H$. pylori Genbank sequences listed in the Table. The Dunnart samples exhibited $100 \%$ sequence identity with $16 \mathrm{~s}$ rRNA from five human clinical isolates of $\mathrm{H}$. pylori, and $96-98 \%$ sequence identity with cagA and ureA from two human clinical isolates of $H$. pylori. 
Table 2 Chronology of events

\begin{tabular}{ll}
\hline Date & \multicolumn{1}{c}{ Event } \\
\hline $\begin{array}{l}\text { July-Dec } \\
2003\end{array}$ & Increased mortality observed in Dunnart colony with gastric bleeding. \\
\hline May 2004 & Two Dunnart stomachs were tested and shown to be Helicobacter positive by CLO test. Histology revealed mild gastritis. \\
\hline $\begin{array}{l}\text { July-Dec } \\
2004\end{array}$ & Increased mortality observed in Dunnart colony with gastric bleeding. \\
\hline 2006 & Dunnart feces shown to be Helicobacter positive by PCR. \\
\hline 2007 & $\begin{array}{l}\text { Dunnart stomachs shown to be Helicobacter positive by PCR. The infection was shown to be H. pylori by partial sequencing of 16S } \\
\text { rRNA, cagA and ureA. }\end{array}$ \\
\hline 2008 & Dunnart colony shown to be Helicobacter negative by PCR of gastric tissues. \\
\hline
\end{tabular}

important feature required for migration of bacteria through the filter paper) or were only present in low levels.

As $H$. pylori infection does not appear to be part of the normal flora of these animals (as it spontaneously cleared between 2007 and 2008) we theorize that H. pylori may have entered this colony as an infection from their human handlers. The concomitant presence of stomach infection with $H$. pylori at the time of the gastric bleeding incidents strongly suggests this bacterium may have contributed to the disease outbreak. Clearly, H. pylori infection alone was insufficient to cause the outbreaks as the infection was present during 2005-2007 without any increase in mortality. However, it may well have been an important co-factor in this process.

The loss of $H$. pylori infection between 2007 and 2008 is intriguing, with the reason for this occurrence remaining unknown. Given Helicobacter were present for at least three years, it was not a short-term phenomenon but was present over many breeding cycles. It therefore seems unlikely that loss of this infection was due to the Helicobacter being out-competed by native flora, although this possibility cannot be excluded. It is also possible that the animals were not transmitting the infection between themselves, but perhaps were being constantly infected by a human handler. If this were the case, the loss of infection may have been due to a change in handler between 2007 and 2008 breaking the infection transmission.

Stress appears to have been an important co-factor in the disease etiology, as the outbreaks occurred during the breeding season in these animals. The breeding season is extremely stressful for both male and female Dunnarts, and in an average year, is accompanied by a considerable loss in body weight. Marsupials can be remarkably sensitive to stress, and it has been shown that stress events can have a major affect on their immune system [22].

Despite this, there must be another co- or causative factor involved in the 2003-2004 outbreaks, as the Dunnarts bred while infected with $H$. pylori in 2005-2007 without any increase in death rate. This co-factor remains unidentified, but does not appear to be anything related to husbandry as there were no changes in the housing conditions of the colony that were associated with either the disease outbreaks or loss of $H$. pylori infection.

In conclusion, we propose that infection with the human pathogen $H$. pylori may have been an essential, though not sufficient co-factor in an outbreak of gastric bleeding resulting in death in a colony of Stripe-faced Dunnarts. The apparent accidental infection of these marsupials by their human handlers, and the association with coincidental gastric pathology, suggests that these animals may provide an interesting novel animal model for the study of $H$. pylori pathogenesis. Further, this observation suggests a potential risk factor to captive marsupials to infections carried by their human handlers.

\section{Acknowledgements}

The authors have no competing interests. We acknowledge the support of Kamani Nanayakkara, Phil Au, Angela Nation and Ellen Menkhorst for animal husbandry and assistance with collection of samples. The colony was supported by funding from the New Zealand Foundation for Science and Technology.

\section{Author details}

${ }^{1}$ Centre for Animal Biotechnology, School of Veterinary Science, The University of Melbourne, Melbourne, VIC 3010, Australia. ${ }^{2}$ Department of Zoology, The University of Melbourne, Melbourne, VIC 3010, Australia. ${ }^{3}$ School of Biotechnology and Biomolecular Sciences, The University of New South Wales, Sydney, NSW 2052, Australia. ${ }^{4}$ Helicobacter Research Lab, School of Biomedical, Biomolecular and Chemical Sciences, University of Western Australia, Perth, WA, Australia.

\section{Authors' contributions}

LS made the initial observation, ran the Dunnart colony and provided samples for analysis. AE, WL, HW, JW, AS and BM performed Helicobacter PCR analyses. NCR, NK and HM performed gene sequencing analyses. AE and PS wrote the manuscript. PS coordinated the study. All authors read and approved the final manuscript.

\section{Competing interests}

The authors declare that they have no competing interests.

Received: 12 September 2010 Accepted: 22 December 2010 Published: 7 February 2011 


\section{References}

1. Warren JR, Marshall B: Unidentified curved bacilli on gastric epithelium in active chronic gastritis. Lancet 1983, 321:1273-1275.

2. Uemura N, Okamoto S, Yamamoto S, Matsumura N, Yamaguchi S, Yamakido M, Taniyama K, Sasaki N, Schlemper RJ: Helicobacter pylori infection and the development of gastric cancer. N Engl J Med 2001, 345:784-789.

3. Yuan Y, Padol IT, Hunt RH: Peptic ulcer disease today. Nat Clin Pract Gastroenterol Hepatol 2006, 3:80-89.

4. Harbour S, Sutton P: Immunogenicity and pathogenicity of Helicobacter infections of veterinary animals. Vet Immunol Immunopathol 2008 , 122:191-203.

5. Haesebrouck F, Pasmans F, Flahou B, Chiers K, Baele M, Meyns T, Decostere A, Ducatelle R: Gastric helicobacters in domestic animals and nonhuman primates and their significance for human health. Clin Microbiol Rev 2009, 22:202-223.

6. Eaton KA, Dewhirst FE, Radin MJ, Fox JG, Paster BJ, Krakowka S, Morgan DR: Helicobacter acinonyx sp. nov., isolated from cheetahs with gastritis. Int J Syst Bacteriol 1993, 43:99-106.

7. Schroder HD, Ludwig C, Jakob W, Reischl U, Stolte M, Lehn N: Chronic gastritis in tigers associated with Helicobacter acinonyx. J Comp Pathol 1998, 119:67-73.

8. Park JH, Lee BJ, Lee YS: Association of tightly spiralled bacterial infection and gastritis in pigs. J Vet Med Sci 2000, 62:725-729.

9. Fox JG, Correa P, Taylor NS, Lee A, Otto G, Murphy JC, Rose R: Helicobacter mustelae-associated gastritis in ferrets. An animal model of Helicobacter pylori gastritis in humans. Gastroenterology 1990, 99:352-361.

10. Eaton KA, Dewhirst FE, Paster BJ, Tzellas N, Coleman BE, Paola J, Sherding R: Prevalence and varieties of Helicobacter species in dogs from random sources and pet dogs: animal and public health implications. J Clin Microbiol 1996, 34:3165-3170.

11. Bryner JH, Ritchie AE, Pollet L, Kirkbride CA, Collins JE: Experimental infection and abortion of pregnant guinea pigs with a unique spirillumlike bacterium isolated from aborted ovine fetuses. Am J Vet Res 1987, 48:91-95.

12. Fox JG, Handt L, Sheppard BJ, Xu S, Dewhirst FE, Motzel S, Klein I: Isolation of Helicobacter cinaedi from the colon, liver, and mesenteric lymph node of a rhesus monkey with chronic colitis and hepatitis. J Clin Microbiol 2001, 39:1580-1585.

13. Harper CG, Feng Y, Xu S, Taylor NS, Kinsel M, Dewhirst FE, Paster BJ, Greenwell M, Levine G, Rogers A, Fox JG: Helicobacter cetorum sp. nov., a urease-positive Helicobacter species isolated from dolphins and whales. J Clin Microbiol 2002, 40:4536-4543.

14. Ceelen L, Decostere A, Martel A, Pasmans F, Haesebrouck F: First report of Helicobacter pullorum in the faeces of a diarrhoeic psittacine bird (Psephotus haematogaster). Vet Rec 2006, 159:389-390.

15. Foley JE, Marks SL, Munson L, Melli A, Dewhirst FE, Yu SL, Shen ZL, Fox JG: Isolation of Helicobacter canis from a colony of Bengal cats with endemic diarrhea. J Clin Microbiol 1999, 37:3271-3275.

16. Selwood L, Cui S: Establishing long-term colonies of marsupials to provide models for studying developmental mechanisms and their application to fertility control. Aust J Zool 2006, 54:197-209.

17. Germani Y, Dauga C, Duval P, Huerre M, Levy M, Pialoux G, Sansonetti $P$, Grimont PA: Strategy for the detection of Helicobacter species by amplification of 16S rRNA genes and identification of $H$. felis in a human gastric biopsy. Res Microbiol 1997, 148:315-326.

18. Chionh $Y T$, Wee $J$, Every AL, Ng GZ, Sutton P: M-cell targeting of whole killed bacteria induces protective immunity against gastrointestinal pathogens. Infect Immun 2009, 77:2962-2970.

19. Nilsson C, Sillen A, Eriksson L, Strand ML, Enroth H, Normark S, Falk P, Engstrand L: Correlation between cag pathogenicity island composition and Helicobacter pylori-associated gastroduodenal disease. Infect Immun 2003, 71:6573-6581.

20. Clayton CL, Kleanthous H, Coates PJ, Morgan DD, Tabaqchali S: Sensitive detection of Helicobacter pylori by using polymerase chain reaction. $J$ Clin Microbiol 1992, 30:192-200.

21. The National Center for Biotechnology Information database. [http:// www.ncbi.nlm.nih.gov].
22. Poskitt DC, Barnett J, Duffey K, Lee AK, Kimpton WG, Muller HK: Stress related involution of lymphoid tissues in Australian marsupial mice. Immunobiology 1984, 166:286-295.

doi:10.1186/1297-9716-42-26

Cite this article as: Every et al:: Did transmission of Helicobacter pylori from humans cause a disease outbreak in a colony of Stripe-faced Dunnarts (Sminthopsis macroura)? Veterinary Research 2011 42:26.

\section{Submit your next manuscript to BioMed Central and take full advantage of:}

- Convenient online submission

- Thorough peer review

- No space constraints or color figure charges

- Immediate publication on acceptance

- Inclusion in PubMed, CAS, Scopus and Google Scholar

- Research which is freely available for redistribution

Submit your manuscript at www.biomedcentral.com/submit
Biomed Central 